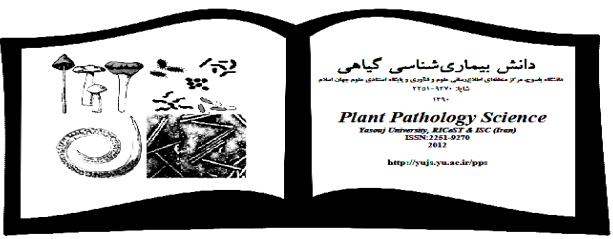

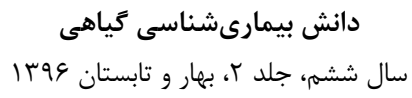

Plant Pathology Science

Vol. 6(2), 2017

\title{
Biological Control of Rhizoctonia Damping-off Disease
}

\section{SAMANEH SAMAVAT ${ }^{\bowtie}$}

Institute of Forests and Rangelands, Agricultural Research, Education and Extension

Organization (AREEO), Tehran, Iran ( $\square$ : samavat.samaneh@gmail.com)

Received: 10.04.2016

Accepted: 03.12.2016

Samavat S. 2017. Biological control of Rhizoctonia damping-off disease. Plant Pathology Science 6(2):55-67.

Abstract: Damping-off caused by Rhizoctonia solani J. G. Kühn is a very important plant disease among soil-borne diseases that make severe damages on a wide range of plants in the world. Biological control of this disease with Trichoderma, Gliocladium, Bacillus, Pseudomonas and Rhizobium species has been reported as a successful management method. The results of some researches on this area and the mechanisms of the effect of these antagonistic fungi and bacteria are described here.

Key words: Damping-off, Rhizoctonia, Pseudomonas, Rhizobium, Trichoderma

$$
\begin{aligned}
& \text { مهار زيستى مرگ ريزوكتونيايى گياهجه } \\
& \text { سمانه سماوات } \\
& \text { مؤسسه تحقيقات جنكل ها و مراتع كشور، سازمان تحقيقات، آموزش و ترويج كشاورزى، تهران }
\end{aligned}
$$

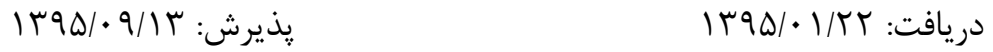

$$
\begin{aligned}
& \text { سماوات س. צو ا. . مهار زيستى مرك ريزوكتونيايى گياهجه. دانش بيمارىشناسى كياهى \&(Y): } \\
& \text { جكيده: مرك كياهجه ناشـى از Rhizoctonia solani J.G.Kühn در بـين بيمـارىهـاى گيـاهى خـاكزاد از }
\end{aligned}
$$

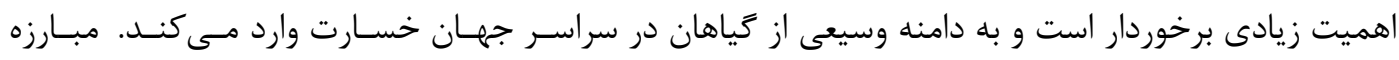

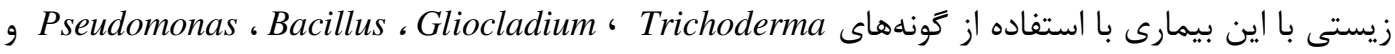

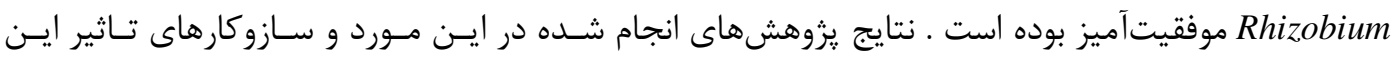

$$
\begin{aligned}
& \text { قارجها و باكترىهاى متعارض شرح داده شدهاند. }
\end{aligned}
$$

وازههاى كليدى: مرى گياهجه، Trichoderma Rhizobium ،Pseudomonas ، Rhizoctonia

بيمارى مرى گياهجه ناشى از Rhizoctonia solani J.G.Kühn به دامنه وسيعى از گياهان در سراسر

$$
\text { جهان خسارت وارد مىكند و در بين بيمارىهاى كياهى خاكزاد از اهميت زيادى برخوردار است. }
$$




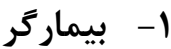

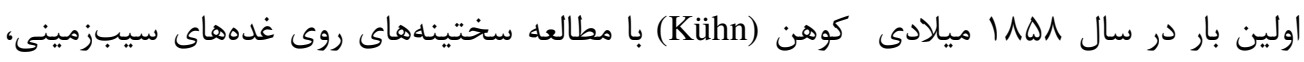

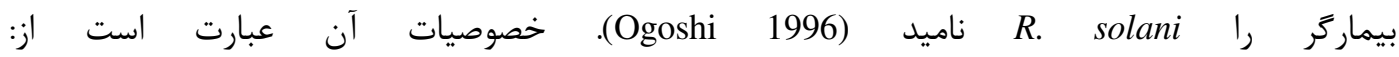
1- رنگ ير گنه قهوهاى روشن تا تيره است، ؟- هر يك از سلولهاى ريسههاى جوان داراى جندين هسته مىباشند، ب- ريسهها در قاعده انشعابات خود داراى فرورفتگى هستند و كمى بالاتر از اين فرورفتكى يكى ديواره عرضى تشكيل مىشود، f- منفذ ديواره عرضى ريسهها از نوع دولييور (dolipore) است، ه- سختينه كاذب تشكيل مىدهند به عبارتى سختينههاى آنها فاقد ديوارههاى متمايز شامل لايه بيرونى (rind) و قسمت ميانى (medulla) مىباشد، צ- فاقد يل إرتباط، هاگ و نماريشه است (Ogoshi 1983). اين قارج بر اساس جوش ريسهاى به f| أ عروه تقسيم شده است كه بهصورت AG-1 تا AG-13 و كروه جدا شده مرتبط AG-BI نشان دادهشهاند، كه برخى از آنها داراى زيركروههايى مىباشند. اترجه اخيراً ييشنهاد شده است كه اين گروه زيرمجموعلى AG-2 است. اين گروهها داراى خصوصيات مشابهى خون ترجيح ميزبانى، بيمارىزايى و نوع نشانهاى بيمارى باشند (Carling et al. 2002, El-Samawaty 2008). قارج Rolani بيماركرى خاكزاد با انتشار جهانى است كه بdصورت يودهرست در خاك رشد مىكند و تجزيه كننده قوى سلولز محسوب مىشود. جدايههاى مختلف آن عامل يوسيدگى بذر، مرى گياهجه (شكل 1)، يوسيدگى ريشه و طوقه و همجنين بيمارىهاى اندامهاى هوايى جون بيمارى سوختگى غلاف برى برنج (Sheath blight ) مىباشد (Burpee and Martin 1992). اين قارج بسيار ولىفاز (Polyphage) است و به

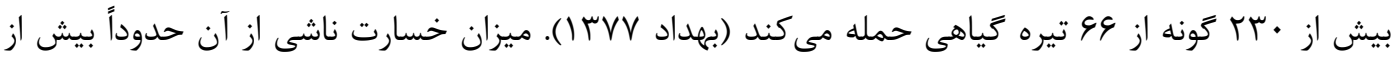

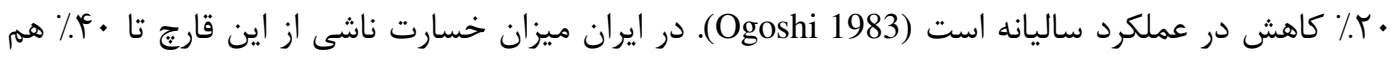

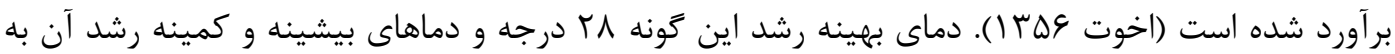
ترتيب أ| و • ا درجه سلسيوس است. اسيديته مناسب براى رشد آن \&/\& تا 9/V مىباشد. همجنين منابع كربن مورداستفاده قارج متعدد است و منابع نيتروزن آن را عمدتاً آرزنين، اورنتين و كليسين تشكيل مىدهد 
اين قارج در شرايط محيطى نامساعد قادر است بلهورت سختينه يا ميسليوم در خاك و يا روى بقاياى كياهى بقا يابد (Lee et al. 2006). با مساعد شدن شرايط محيطى، محركهاى شيميايى موجود در تراوشات بذور و يا ريشه گياهجهها كه در منطقه فراريشه رهاسازى مى مذكور به سمت آن ميزبان مىشوند. در يى آن، ريسه قارج در تماس مستقيم با گياه ميزبان قراركرفته و به سطوح خارجى اندامهاى زيرزمينى آن مى جسبد. پِ از اتصال، قارج بر روى ميزبان مستقر مىشود و به رشد خود بر روى سطح خارجى اندامهاى زيرزمينى آن ادامه مىدهد. در يى آن ميسليوم قارج با رشد كردن و ييجيدن به دور خود و جوانهزنىهاى مكرر، كوتاه و متورم شده و به اين ترتيب با تشكيل بالشتك واگيرش يا

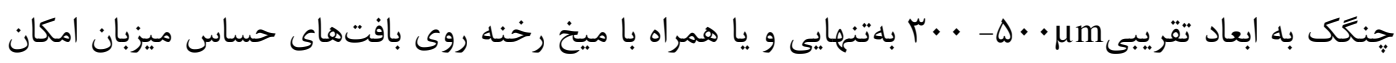
نفوذ قارج فراهم مى گردد. به اين صورت نفوذ مستقيم به كمك ميخ رخنه و از طريق فشارهاى مكانيكى انجام مىشود. همجنين ممكن است كياهجهها بهآسانى از محل شكافها و يا زخمهاى موجود بر روى اندامهاى زيرزمينى مورد حمله قرار گيرند. بهمحض اينكه إييدرم گياه مورد نفوذ قرار گرفت، قبل از اينكه نشانهها در ميزبان بروز نمايد، قارج بهصورت درونسلولى و بين سلولى استقرار و گسترش مىيابد. به دنبال آن كسب تركيبات غذايى براى توسعه و رشد مداوم قارج ميسر مىشود و فرايند آلودگى با توليد دامنهاى از آنزيمهاى خارج سلولى تجزيهكننده اجزاى مختلف ديواره سلولى ميزبان (سلولز، يكتين و كوتين) ادامه مي يابد. با توليد تركيبات آنزيمى، بىرنخ شدن و فروريختن بافتها رخ مىدهد و به اين صورت محيطى مناسب براى استفاده قارج فراهم مىشود كه گاهى بلهورت يك زخم فرورفتهى قهوهاىرنت در محور زير لِه گياهجه يديد مى آيد(شكل (). با افزايش رشد كياهجهها، به دليل افزايش در ضخامت إيبدرم، جوبى شدن و كاهش
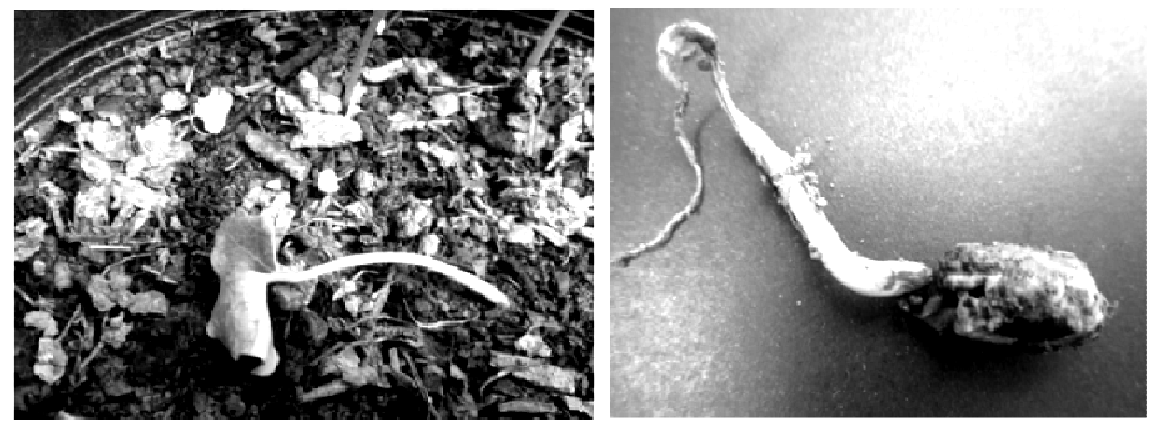

شكل ا- نشانههاى مرى گَياهجه ينبه ناشى از قارج (R. solani (AG-4) در كلخانه .

Figure 1. The symptoms of cotton seedling damping-off caused by $R$. solani in the green-house 
ترشحات ريشه، ميزبان نسبت به نفوذ قارج مقاومتر مىشود. بهتدريج با توسعه آلودگى، مرگ سلولهاى كياهى رخ مى دهد و ريسههاى قارج به رشد و اشغال كردن بافتهاى مرده ادامه مىدهند كه در اغلب مواقع با تشكيل سختينه همراه مىباشد. در شرايطى كه رطوبت خاك در سطح مطلوب باشد، رشد ميسليومهاى قارج بهراحتى از موضع آلودگى قابلرؤيت مىشود و كاهاً تا عمق جند سانتىمترى از سطح خاك پيشروى مىنمايد. همينطور ظهور مرحله جنسى قارج و توليد بازيديوسيورها بر روى طوقه و در مجاورت سطح خاك در شرايط محيطى خاص با رطوبت نسبى بالا رخ مىدهد. در بیى كذراندن شرايط نامساعد محيطى، مايه تلقيح جديد قارج بر روى يا درون بافت ميزبان مجدداً توليد مىشود و به اين ترتيب با در دسترس بودن شرايط مساعد جرخه بيمارى جديدى تكرار مىشود (Schippers and Gams 1979, Ceresini et al. 1999).

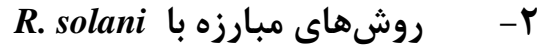

بلهور كلى مبارزه با قارجهاى بيمارگر خاكزاد به سه دليل دشوار مىباشد. نخست اينكه قارجهاى مذكور انكَل اختيارى هستند و علاوه بر گياه زنده روى بقاياى گياهى مرده نيز مىتوانند بقا يابند. دوم اينكه اين قبيل قارجها معمولاً ميزبانهاى گياهى متعددى دارند. سوم اينكه قارجهاى مزبور بسيار مقاوم هستند و تا مدت طولانى مىتوانند در خاك بقا يابند (Vargas et al. 2008). با اين حال برخى از روشهاى مرسوم براى

$$
\text { مبارزه اين بيمارگر عبارت است از: }
$$

ז-1- مبارزه شيميايى: تيمار بذور قبل از كاشت با سمومى خون تيرام، كاربندازيم، بنوميل، مانكوزب، زينب، آييروديون، ويتاواكس و يا تيابندازول در مبارزه اين بيمارى مرسوم است (صادقى خامنه اى تبريزى

r-r- مبارزه زراعى: آيش، تناوب زراعى با گياه غير ميزبان، حذف بقاياى گياهى آلوده، كاشت ارقام مقاوم، زهكشى خاك و عدم كشت كرتى بوتهها بهمنظور مبارزه اين بيماركر به كار مىروند. اين در حالى است كه روشهاى مبارزه زراعى و شيميايى مرسوم بهطور كامل مؤثر نيستند و اين امر منجر گرديده است تا بيمارى

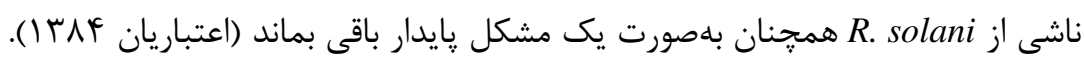


r-r- مبارزه زيستى: كاربرد نامناسب آفت كشها و كودهاى شيميايى در طى ساليان متمادى منجر به بروز مشكلات عديدهاى جون آلودگى خاى زمينهاى زير كشت، آلودگى آبهاى زيرزمينى و شورى خاك در كشاورزى شده است. از طرفى تأثير اندى و كمدوام روشهاى شيميايى در مبارزه بيماركرهاى كَاهى خاكزاد، هزينههاى بالاى اقتصادى آن، نغرانىهاى زيستمحيطى ناشى از پِماندهاى مواد شيميايى و ايجاد مقاومت در بيمارگرها باعث شده است تا به امروز تلاش بسيارى در جهت كاهش مصرف جنين تركيبات شيميايى بهمنظور بالا بردن سطح كيفيت خاك و تحقق كشاورزى پايدار صورت كيرد كه از آن جمله مىتوان به كاربرد قارجها و باكترىهاى متعارض بهعنوان سموم و كودهاى زيستى اشاره كرد (Khabbaz et al. 2015).

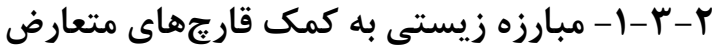

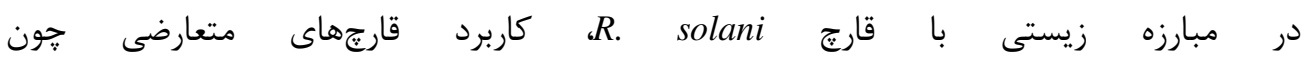

. T. viridae Pers..Trichoderma harzianum Rifai. ‘Gliocladium virens J. H. Mill. T. atroviride Bisset. T. koningii Oudem. (Reithner et al. 2007, Kandula et al. 2015) قارج Rolani را تحت تأثير قرار مىدهند. از ديكر سازوكارهاى مبارزه زيستى اين قارجهاى متعارض مىتوان به رقابت با قارج بيمارگر بر سر مواد غذايى و يا اشغال فضا (Harman et al. 2004) و نيز القاى مقاومت سيستميك (آزادديسفانى و همكاران كوץ (1) اشاره كرد. علاوه بر اين با اثراتى كه بر تحريك رشد كياه دارند مىتواند منجر به تغيير در شرايط خاك شود و در نتيجه در مبارزه غيرمستقيم بيمارگر نقش داشته باشد .(Kandula et al. 2015)

\section{r-r-r-r- مبارزه زيستى به كمك باكترىهاى متعارض}

باكترىهاى متعارض بهطور ويزهاى جهت كاربرد بهعنوان عوامل مبارزه زيستى در كشاورزى مناسب هستند به اين دلايل كه: ا - آنها مىتوانند از تركيبات مترشحه بسيارى بهعنوان منبع غذايى استفاده كنند، r- بلوفور در خاكهاى طبيعى، بلويزه روى ريشه كَاهان، موجود هستند، س- داراى نرخ تكثير بسيار بالاترى نسبت به ساير باكترىهاى موجود در فراريشه هستند، F- داراى توانايى توليد متابوليتهاى ضدميكروبى 
هستند، ه- آنها به سهولت در شرايط آزمايشعاهى تكثير مىشوند، و- مىتوانند با آغشتهسازى بذر به باكترىها مجدداً به فراريشه وارد شوند، V- قادر به القاى مقاومت سيستميك نسبت به بيمارگرهاى گياهى هستند ) Van Loon et al. 1998, Pieterse et al. 2001, Lugtenberg et al. 1991a,b, Dunlap et al. (1996, Dowling and O’Gara 1994 سويههايى از باكترىهاى سودوموناسهاى فلورسنت، .Bacillus subtilis Ehrenberg و نيز Rhizobium spp. Beijerinck.

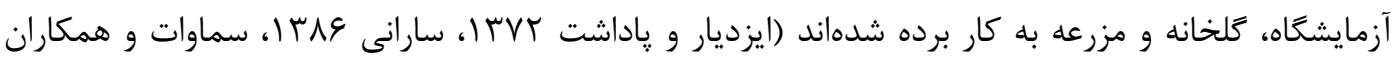

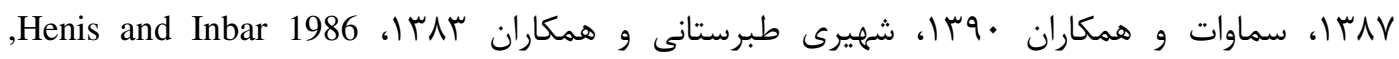
Hagedorn et al. 1989, Nagarajkumar et al. 2004, Samavat et al. 2011 فرمولاسيونهاى جديد تهيهشده از سويه وحشى Pseudomonas aureofaciens Kluyver. (30-84) و سويه جهشيافته آنكه به ترتيب دارا و فاقد توانايى در توليد آنتىبيوتيك فنازين بودند و بهكاركيرى آنها بهصورت تيمار بذر، مشخص شد كه شيوع و شدت بيمارى مرى گياهجه ينبه ناشى از قارج (AG-4) solani (Adطور معنىدارى در تيمارهاى تهيهشده از سويه وحشى كاهش يافت، كه اين امر حاكى از نقش آنتىبيوتيك فنازين در مبارزه كارآمد اين بيماركر است (Samavat et al. 2014b) مبارزه با بيماركر با سويههاى مختلف باكترىها نشان داده كه سازوكار مبارزه زيستى آنها روى اين بيماركر ممكن است عمدتاً از نوع القاى مقاومت سيستميك و يا توليد انواعى از آنتىبيوتيكها باشد (Nandakumar et al. 2001). از جمله مهمترين اين آنتىبيوتيكها مىتوان به تر كيباتى نظير ؟ و \& دى استيل فلوروكلوسينول (2,4-diacetylphloroglucinol)، فنازين (Phenazine)، يايولوتئورين (Pyoluteorin)، اگروسين Af (Agrocin84)، هربيكولين (Herbicolin)، Ge et al. 2004, Girard et al. 2006, ) اشارمايسين (Oomycin) (بيرول نيترين (Pyrrolnitrin) Girard et al. 2006, Howie and Suslow 1991, Keel et al. 1992, Schippers et al. 1987, Caroll et al. 1995). همينطور اين باكترىهاى مفيد ممكن است از ديخر سازوكارهاى مبارزه زيستى نظير توانايى در توليد آهنبرهاى ميكروبى (Leong 1986, Schippers et al. 1987)، سيانيد هيدروزن (Voisard et al. 1989) و آنزيمهاى هضمكننده سلولى نظير يروتئز نيز برخوردار باشند(Keel and Defago 1997). 
نتايج حاصل از بررسىهاى آزمايشگاهى حاكى از اين است كه از بين جدايههاى باكترى

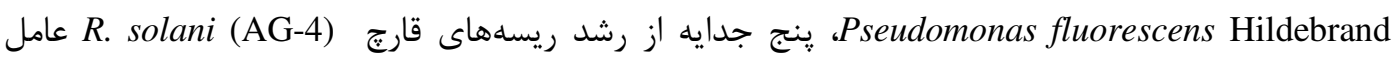
يوسيدگى بذر و مرك گياهجه ينبه طى آزمون كشت متقابل ممانعت به عمل آوردند. در حقيقت مىتوان كفت كه آنتىبيوتيكهاى توليد شده توسط اين جدايههاى باكتريايى طى سازوكار پادزيستى منجر به اين امر شده است. همجنين بررسىهاى آزمايشعاهى نشان داد كه اين باكترىها از توانايى در توليد آهنبر، متابوليتهاى ضدقارجى فرار و غيرفرار نيز برخوردار هستند. تيمار بذور زنبه توسط سوسيانسيونهاى تهيهشده از اين جدايههاى باكتريايى منجر به كاهش شيوع و شدت بيمارى يوسيدگى بذر و مرك گياهجه ينبه تحت شرايط كَلخانه شد. اين در حالى است كه جدايههاى مختلف از اين نظر از توانايى مختلفى برخوردار بودند (Samavat et al. 2014a). علاوه بر اين، جدايههاى باكتريايى متعلق به گونههاى Rhizobium etli) Segovia. بيمارى :وسيدگى بذر و مرگ گياهجه لوبيا سبز تحت شرايط آزمايشگاهى و گلخانه برخوردار بودند. اين جدايهها قادر به توليد متابوليتهاى ثانويه ضدقارجى نظير هيدروزن سيانيد، آهن بر و آنزيم يروتئز بودند. تيمار بذور لوبيا توسط سوسيانسيون آنها نهتنها منجر به كاهش شدت بيمارى شد بلكه تحريك رشد بوتهها را نيز منجر گرديد (سماوات و همكاران •وبا)). مقايسه اثرات متعارضى هفت جدايه از Rhizobium با هفت جدايه از باكترى Pseudomonas عليه r. solani (AG-4) عامل بيمارى يوسيدگى بذر و مرك گياهجه لوبيا سبز نشان داد كه برخى از جدايههاى Rhizobium از قابليت بيشترى به لحاظ تحريك رشد گياه و نيز مبارزه بيمارى در قياس با ساير جدايهها برخوردار بودند. اين امر امكان بهكارگيرى جدايههاى Rhizobium بهعنوان سموم و كودهاى زيستى در سيستمهاى كشاورزى يايدار را محقق مىسازد (سماوات و همكاران YNVI).

\section{نتيجه كيرى و وييشنهاد}

دشوارى، صرف هزينههاى بالا، مسائل زيستمحيطى و ناكار آمدى روشهاى معمول مبارزه شيميايى و

زراعى عليه بيمارى مرى گَياهجه ناشى از Rolani .R، ضرورت بهكارگيرى روشهاى جايگزين جون مبارزه زيستى را نشان مىدهد. در اين راستا قارجهاى متعارض عمدتاً با برخوردارى از سازوكارهايى جون توليد انواعى از آنتىبيوتيكها، آنزيمهاى هضمكننده سلولى، رقابت، القاى مقاومت سيستميك، قارج- انخلى و 
تخريب ريسهها و باكترىهاى متعارض نيز از طريق توليد طيفى از آنتىبيوتيكها و القاى مقاومت سيستميك منجر به مهار اين بيمارگر مىشوند. به اينترتيب اين ريزجانداران مفيد مىتوانند در آيندهاى نزديك از جايكاه ويزهاى در مبارزه زيستى با اين بيمارى برخوردار گردند. بنابراين بررسى جدايههاى بومى و سازگار باكترىهاو و قارجهاى به لحاظ توانايى در مبارزه زيستى با اين بيماركر خاكزى و مطالعه سازوكارهاى مختلف تاثير آنها، براى انتخاب برترين جدايهها در قالب فرمولاسيونهاى تجارتى ييشنهاد مى گردند.

\section{References}

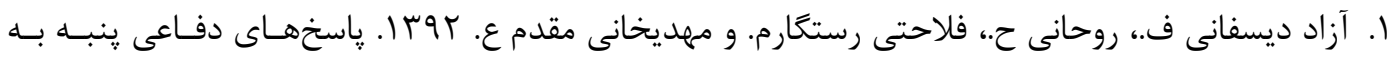
كونههاى قارج تريكودرما و اثر آن در مبارزه بيمارى مرى كياهجه ناشى از Rhizoctonia solani. حفاظـت

$$
\text { كيlolid }
$$

ז. اخوت م. צهاץ ا. بررسى اثر جند قارجكش بر Rhizoctonia solani Kuhn عامـل بوسـيدگى بـذر و مـرى

$$
\text { كياهجه لوبيا (Phaseolus vulgaris L.). بيمارىهاى كياهى سا: 1-1. }
$$

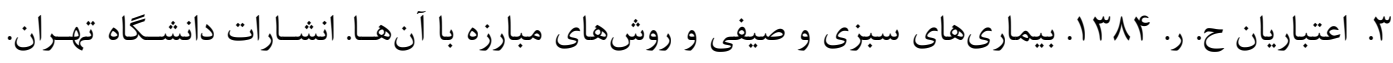

$$
\text { ص } \Delta \Delta \mathrm{r}
$$

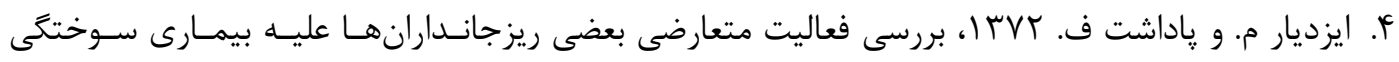

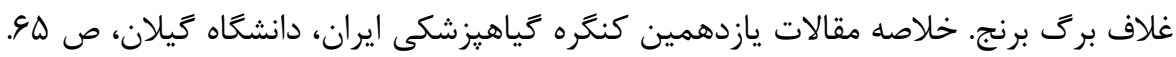

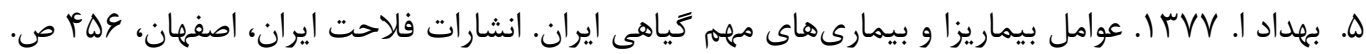
צ. سارانى ش.ا.، شريفى تهرانى ع.، احمدزاده م. و جوان نيكخواه م. ع^ب ا. كارايى باكترىهاى سودوموناس در مبارزه بيولوزيكى Rhizoctonia solani عامل مرى كياهجه كلزا. علوم و فنون كشاوززى و منسابع طبيعى

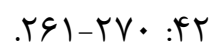

V. سماوات س. rوج ا. مطالعـه فعاليـت متعـارض بـاكترى Pseudomonas aureofaciens (انـواع وحشى و موتانت فاقد زن تنظيم كننده آنتىبيوتيك فنازين) عليه جند قارج بيماركر گينبه و تهيه جنــد فرمولاسـيون از آن. رساله دكترى. دانشعاه آزاد اسلامى واحد علوم و تحقيقات تهران. 1 • اص. 
^. سماوات س.، احمدزاده م و بهبودى ك. • وץ ا. معرفى برخى جدايههاى Rhizobium spp به عنوان عوامـل

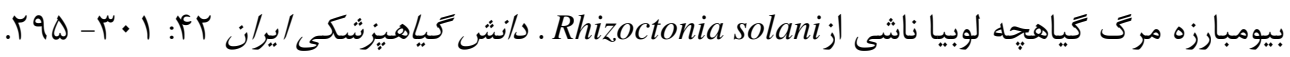

9. سـماوات س.، احمــزاده م.، بهبـودى ك. و بشـارتى ح. INVV. مقايسـه توانـايى جدايـههـاى ريزوبيـوم و

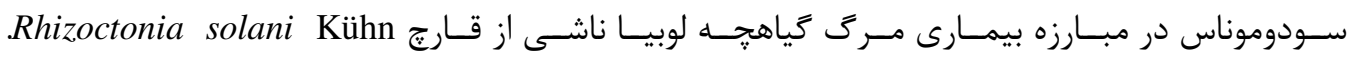

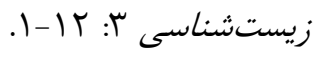

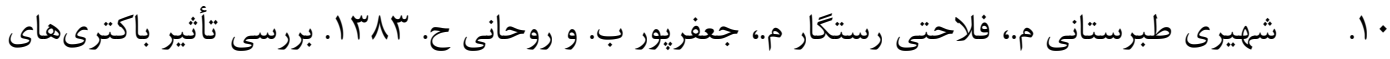

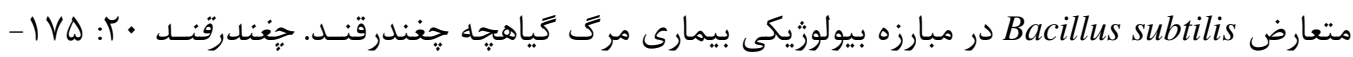

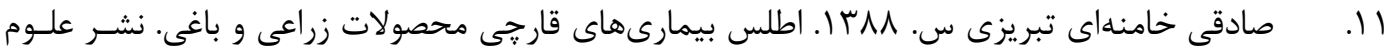

$$
\begin{aligned}
& \text { كشاورزى ايران، ويراست دوم، TVG ص. }
\end{aligned}
$$

12.Blazier S. R. and Conway K. E. 2004. Characterization of Rhizoctonia solani isolates associated with patch diseases on turf grass. In Proceedings of the Oklahoma Academy of Science 84:41-51.

13.Burpee L. L. and Martin B. 1992. Biology of Rhizoctonia species associated with turf grasses. Plant Disease 76:112-117.

14.Carling D. E., Baird R. E., Gitaitis R. D., Brained K. A. and Kuninaga S. 2002. Characterization of AG-13, a newly reported anastomosis group of Rhizoctonia solani. District Control Pest Management 92:893-899.

15.Caroll H., Moenne-Loccoz Y., Dowling D. and Ogara F. 1995. Mutational disruption of the biosynthesis genes coding for the antifungal metabolite 2,4-diacetylphloroglucinol does not influence the ecological fitness of Pseudomonas fluorescens F113 in the rhizosphere of sugar beets. Applied Environmental Microbiology 61:3002-3007.

16.Ceresini P. C., Shew H. D. and Cubeta M. A. 1999. RFLP analysis of the PCR amplified ribosomal DNA regions ITS and IGS indicated that isolates of Rhizoctonia solani from potato and tobacco represent distinct groups within the anastomosis group 3. Phytopathology 89: S12.

17.Claydon N., Allan M., Itanson J. R. and Avent A. G. 1987. Antifungal alkyl pyrones of Trichoderma harzianum. Transactions of the British Mycological Society 88:503-513. 
18.Cruz J., Hildalgo-Gallego A., Lora J. M., Benitez T., Pintor-Toro J. A. and Llobel A. 1992. Isolation and characterization of three chitinases from Trichoderma harzianum. European Journal of Biochemical 206:859-867.

19.Dennis C. and Webster J. 1971. Antagonistic properties of species-groups of Trichoderma: II. Production of volatile antibiotics. Transactions of the British Mycological Society 57:4148.

20.Dowling D. N. and O'Gara. F. 1994. Metabolites of Pseudomonas involved in the biocontrol of plant disease. Trends in Biotechnology 12:133-141.

21.Dunlap C., Delaney I., Fenton A., Lohrke S., Moënne-Loccoz, Y. and O'Gara F. 1996. The Biotechnology And Application Of Pseudomonas Inoculants For The Biocontrol Of Phytopathogens. pp. 441-448. In: G., Stacey B., Mullin P. M. Gresshoff (ed.). Biology of Plant Microbe Interactions. St Paul, MN, USA.

22.Elad Y., Barak R. and Henis Y. 1983. Ultrastructural studies of the interaction between Trichoderma spp. and plant pathogenic fungi. Phytopathologische Zeitschrift 107:168-175.

23.Elad Y., Sadwosky Z. and Chet I. 1987. Scanning electron microscopical observations of early stages of interaction of Trichoderma harzianum and Rhizoctonia solani. Transactions of the British Mycological Society 88:259-263.

24.El-Samawaty A. M. A., Amal A., Asran M. R. and Omar Abd-Elsalam K. A. 2008. Anastomosis Groups, Pathogenicity, and Cellulase Production of Rhizoctonia solani from Cotton. Pest Technology 1:117-124.

25.Faull J. L., Graeme-Cook K. A. and Pilkington B. L. 1994. Production of an isonitrille antibiotic by an UV-induced mutant of Trichoderma harzianum. Phytochemistry 36:12731276.

26.Galli E., Silver S. and Witholt B. 1992. Pseudomonas: molecular biology and biotechnology. Washington DC, UK, American Society for Microbiology. 301-313.

27.Ge Y., Huang X., Wang S., Zhang X. and Xu Y. 2004. Phenazine-1-carboxylic acid is negatively regulated and pyoluteorin positively regulated by gacA in Pseudomonas sp. M18. FEMS Microbiology Letters 237:41-47.

28. Girard G., Lugtenberg B. J. J. and Bloemberg G. V. 2006. Regulatory roles of psrA and rpoS in phenazine-1-carboxamide synthesis by Pseudomonas chlororaphis PCL1391. Microbiology 152:43-58.

29.Gutterson N. 1990. Microbial fungicides: recent approaches to elucidating mechanisms. Critical Reviews in Microbiology 10:69-91. 
30.Hagedorn C., Gould W. D. and Bradinelli R. T. 1989. Rhizobacteria of cotton and their repression of seedling disease pathogens. Applied Environmental Microbiology 55:27932797.

31.Harman G. E., Howell, Ch. R., Viterbo A., Chet I. and Lorito Mateo. 2004. Trichoderma species: opportunistic, avirulent plant symbionts. Nature Reviews Microbiology 2:43-56.

32.Henis Y. and Inbar M. 1986. Effect of Bacillus subtilis on growth and sclerotium formation by Rhizoctonia solani. Phytopathology 58:933-938.

33.Howell C. R. and Stipanovic R. D. 1979. Control of Rhizoctonia solani on cotton seedlings with Pseudomonas fluorescens and with an antibiotic produced by the bacterium. Phytopathology 69:480-482.

34.Howie W. J. and Suslow T. V. 1991. Role of antibiotic biosynthesis in the inhibition of Pythium ultimum in the cotton spermosphere and rhizosphere by Pseudomonas fluorescens. Molecular Plant-Microbe Interactions 4:393-399.

35.Kandula D. R., WJones E. E., Stewart A., McLean K. L. and Hampton J. G. 2015. Trichoderma species for biocontrol of soil-borne plant pathogens of pasture species. Biocontrol Science and Technology 25:1052-1069.

36.Keel C. and Defago G. 1997. Interactions Between Beneficial Soil Bacteria and Root Pathogens: Mechanisms and Ecological Impact. In: Pp: 27-46. A. G. Gange. And V. K. Brown (ed.). Multitrophic Interactions in Terrestrial Systems. Blackwell Scientific, London.

37.Keel C., Schnider U., Maurhofer M., Voisard C., Laville J., Burger U., Wirthner P., Hass D. and Defago G. 1992. Suppression of root disease by Pseudomonas fluorescens CHA0: Importance of the bacterial secondary metabolite 2,4-diacetylphloroglucinol. Molecular Plant-Microbe Interactions 5:4-13.

38.Khabbaz S. E., Zhang L., Cáceres L. A., Sumarah M., Wang A. and Abbas P. A. 2015. Characterisation of antagonistic bacillus and pseudomonas strains for biocontrol potential and suppression of damping-off and root rot diseases. Annals of Applied Biology 166:456471.

39.Lee J., Bricker T. M., Lefevre M., Pinson S. R. M. and Oard J. H. 2006. Proteomic and genetic approaches to identifying defencerelated proteins in rice challenged with the fungal pathogen Rhizoctonia solani. Molecular Plant Pathology 7:405-416.

40.Leong J. 1986. Siderophores: their biochemistry and possible role in biocontrol of plant pathogens. Annual Review of Phytopathology 24:187- 209.

41.Loper J. E. 1988. Role of fluorescent siderophore production in biological control of Pythium ultimum by a Pseudomonas fluorescens strain. Phytopathology 78:166-172. 
42.Lorito M., Hayes C. K., Dipietro A., Woo S. L. and Harman G. E. 1993. Purification, characterization and synergistic activity of a glucan-b-1,3-glucosidase and a N-acetyl-Bglucosaminidase from Trichoderma harzianum. Phytopathology 84:398-405.

43.Lugtenberg B. J. J., de Weger L. A. and Bennett J.W. 1991a. Microbial stimulation of plant growth and protection from disease. Current Opinion in Biotechnology 2:457-464.

44.Lugtenberg- B. J. J., Dekkers L. C., Bansraj M., Bloemberg G. V. Camacho M., Chin-AWoeng T. F. C., Van Den Hondel C., Kravchenko L., Kuiper I., Lagopodi A. L., Mulders I., Phoelich C., Ram A., Tikhonovich I., Tuinman S., Wijffelman C. and Wijfjes A. 1999b. Pseudomonas Genes and Traits Involved in Tomato Root Colonization. Biology of PlantMicrobe Interactions 2:25-30.

45.Nagarajkumar M., Bhaskaran R. and Velazhahan R. 2004. Involvement of secondary metabolites and extracellular lytic enzymes produced by Pseudomonas fluorescens in inhibition of Rhizoctonia solani, the rice sheath blight pathogen. Microbiology Research 159:73-81.

46.Nandakumar R., Babu S.R., Viswanathan J., Sheela T., Raguchander S. and Samiyappan R. 2001. A new bio-formulation containing plant growth promoting rhizobacterial mixture for the management of sheath blight and enhanced grain yield in rice. Biocontrol 46:493-510.

47.Ogoshi A. 1996. Rhizoctonia Species: Taxonomy, Molecular Biology, Ecology, Pathology and Disease Control. In: PP. 1-9. B., Sneh S., Jabaji-Hare S., Neate G., Dijst Kluwer (ed.). Academic The Genus Rhizoctonia. Publishers, Dordrecht.

48.Ogoshi A., Oniki M., Araki, T. and Ui T. 1983. Studies on the anastomosis groups of binucleate Rhizoctonia and thier perfect states. Journal of the Faculty of Agriculture, Hokkaido University, Japan 61:244-260.

49.Pieterse C. M. J., Van Pelt J. A., Van Wees S. C. M. Ton J., Leon-Kloosterziel K. M., Keurentjes J. J. B., Verhagen B. W. M., Van Knoester M. D. S. I., Bakker P. A. H. M. and Van Loon L. C. 2001. Rhizobacteria-mediated induced systemic resistance: triggering, signalling and expression. European Journal of Plant Pathology 107:51-61.

50.Reithner B., Schuhmacher R., Stoppacher N., Pucher M., Brunner K. and Zeilinger S. 2007. Signaling via the Trichoderma atroviride mitogen-activated protein kinase Tmk1 differentially affects mycoparasitism and plant protection. Fungal Genetic Biology 44:11231133 .

51.Samavat S., Besharati H. and Behboudi K. 2011. Interactions of Rhizobia cultural filtrates with Pseudomonas fluorescens on bean damping-off control. Journal of Agricultural Science Technology 13:965-976. 
52.Samavat S., Heydari A., Zamanizadeh H.R., Rezaee S. and Alizadeh Aliabadi A. 2014a. A comparison between Pseudomonas aureofaciens and P. fluorescens in biological control of cotton seedling damping-off disease. Journal of Plant Protection Research 54:115-121.

53.Samavat S., Heydari A., Zamanizadeh H.R., Rezaee S. and Alizadeh Aliabadi A. 2014b. Application of new bioformulations of Pseudomonas aureofaciens for biocontrol of cotton seedling damping-off. Journal of Plant Protection Research 54:334-339.

54.Schippers B. and Gams W. 1979. Soil-Borne Plant Pathogens. 685p.

55.Schippers B., Bakker A. W. and Bakker P. A. H. M. 1987. Interactions of deleterious and beneficial rhizosphere microorganisms and the effect of cropping practices. Annual Review of Phytopathology 25:339-358.

56.Sivan A. and Chet I. 1989. Degradation of fungal cell walls by lytic enzymes of Trichoderma harzianum. Journal of General Microbiology 135:675-682.

57.Van Loon L. C., Bakker P. A. H. M. and Pieterse C. M. J. 1998. Systemic resistance induced by rhizosphere bacteria. Annual Review of Phytopathology 36:453- 483.

58.Vargas S., Gil R., Haro C., Oddino M., Kearney M., Zuza A. and Marinelli G. J. 2008. Crop management practices in the control of peanut diseases caused by soilborne fungi. Crop Protection 27: 1-9.

59.Voisard C., Keel C., Haas D. and De`fago G. 1989. Cyanide production by Pseudomonas fluorescens helps suppress black root rot of tobacco under gnotobiotic conditions. The EMBO Journal 8:351-358. 